Szalai, Anna. "Mandler, David. 2014. Kelet és nyugat mezsgyéjén - Vámbéry Ármin és a Brit Birodalom ('On the Border between East and West - Arminius Vámbéry and the British Empire'). Budapest: Múlt és Jövő Kiadó. 223 pp." Hungarian Cultural Studies. e-Journal of the American Hungarian Educators Association, Volume 8 (2015): http://ahea.pitt.edu DOI: 10.5195/ahea.2015.205

\title{
Mandler, David. 2014. Kelet és nyugat mezsgyéjén - Vámbéry Armin és a Brit Birodalom ('On the Border between East and West - Arminius Vámbéry and the British Empire'). Budapest: Múlt és Jövő Kiadó. 223 pp.
}

\section{Reviewed by Anna Szalai, Independent Scholar, Israel}

The centennial of the death of the famous Orientalist Ármin(ius) Vámbéry (1831/321913) was commemorated in Hungary in numerous events. In the framework of the Vámbéry commemoration year, the Hungarian Academy of Sciences (Magyar Tudományos Akadémia, MTA) organized, in cooperation with other institutions, an international conference inviting well known researchers from Germany, the United States, Turkey and Israel. The participants were all knowledgeable about Vámbéry's political and public career as well as with his role in the Russian-British struggle concerning the Middle East, including Vámbéry's relations with both the Zionist and the Pan-Turkish Movements. In addition to the MTA conference an exhibition titled Keletkutató dervisruhában ('An Orientalist Clad in a Dervish Robe') and a website about Vámbéry's life and work were also set up in Budapest.

Following the Vámbéry commemoration events, a large part of the August 2013 issue of the Journal of the MTA was devoted to studies about Vámbéry. These articles present Vámbéry's manifold expertise and activities: he was the first Hungarian Near-East and Middle-East expert, he embarked on discovery journeys among Turkish nations living in Central Asia and Afghanistan, he was an expert on the Russian-British conflict (termed "The Great Game" by British Intelligence Officer Arthur Conolly, 1807-1842), he studied the linguistic connections between the Hungarian and the Turkish languages, he formed relations with the Turkish Reform Movement, he initiated Oriental language studies at the University of Pest and was the founder of the Hungarian Geographic Society (A Magyar Földrajzi Társaság). In addition to all these, his activities as a publicist drew international attention, especially that of the English public, and he also acted as a spy for both the Ottoman and the British Empires.

The articles in the August 2013 MTA issue focus on Vámbéry's Jewish origin, his outstanding skill for languages, the unknown territories he explored, often while accompanied by dangerously suspicious locals, and his extraordinary ability to adjust to different environments. Some of these articles also point out that the most valuable part of the Oriental Collection (Keleti Gyüjtemény) in the MTA Library at Budapest relates to Vámbéry's works, his Jewish origin, connection to Zionism and the role he played in the 1901 meeting of Theodore (Tivadar) Herzl (1860-1904), the Hungarian-Jewish founder of the World Zionist Organization and of modern political Zionism, with the Turkish Sultan Abdul Hamid II concerning the settlement of Jews in the Ottoman Empire and especially in Israel/Palestine.

David Mandler's study on Vámbéry appeared, albeit with some delay, on the occasion of the Commemoration Year, under the auspices of the Múlt és Jövö ['Past and Future'] Hungarian Jewish cultural publication, whose publishers wished to revive Vámbéry's somewhat neglected

(cc) $\mathrm{Br}$

ULLS D-Serle
New articles in this journal are licensed under a Creative Commons Attribution 4.0 International License.

This journal is published by the University Library System of the University of Pittsburgh as part of its D-Scribe Digital Publishing Program and is cosponsored by the University of Pittsburgh Press 
Szalai, Anna. "Mandler, David. 2014. Kelet és nyugat mezsgyéjén - Vámbéry Ármin és a Brit Birodalom ('On the Border between East and West - Arminius Vámbéry and the British Empire'). Budapest: Múlt és Jövő Kiadó. 223 pp." Hungarian Cultural Studies. e-Journal of the American Hungarian Educators Association, Volume 8 (2015): http://ahea.pitt.edu DOI: 10.5195/ahea.2015.205

memory that is in no way comparable to the acclaim he won in England and Turkey. Mandler's book, which is based on his 2005 English language doctoral dissertation at New York University (Arminius Vámbéry, the Eastern (br)other in Victorian Politics and Culture: Hungarian (Jewish) Orientalism and the Invention of Identities), illuminates Vámbéry's career from an innovative angle that contributes to a better understanding of his biography, scientific work and complex Jewish-Protestant identity. Unlike the organizers of the Vámbéry commemoration events, who looked for connecting threads in the life and work of Vámbéry as a researcher who played a meaningful political role in the geopolitical context of his time, Mandler deliberately focuses on those aspects of Vámbéry's career that portray him as an Orientalist of Jewish origin with an undecided or undefined identity.

Ármin Vámbéry was born in Szentgyörgy (presently in Slovakia) as Hermann Wamberger (or Bamberger according to some sources) and it was his family and financial condition that determined his education. Following a traditional Jewish primary-school education, he proceeded to the Piarist Catholic School for poor children and then to the St. Benedict's Monks School; he left the established educational institutions altogether without completing his matriculation exams and turned himself into an autodidact researcher, yet his extraordinary memory and learning abilities enabled him to learn thirty-two languages, eighteen of which he purportedly spoke perfectly. Mandler emphasizes Vámbéry's tendency toward roleplaying, as exemplified in the several autobiographical volumes he wrote, in which he was systematically evasive about his Jewish origin. Through his journeys to the East, his popularity in England and his influence in the court of the Turkish Sultan, Vámbéry discovered his adaptability and ability to assimilate in any environment. The process that Vámbéry underwent during his travels in Turkey and Central Asia can be traced in the way he dressed. To the end of his days he wore a fez and when travelling through unknown lands and meeting with their inhabitants he often dressed like a beggar dervish. It seems that he donned forever changing new roles to suit the circumstances he was in or as a precondition for his successful and safe return from his journeys.

Vámbéry's trip to Central Asia was motivated by two goals. Although the MTA appointed him as a correspondent member of academic authority to join the search after the Asiatic origins of Hungarians, Vámbéry did not even take along the MTA recommendation letter written in Latin, as throughout his journey he had to conceal his European origin. Instead of this document he used Turkish recommendation letters placing him under the protection of the Sultan in which he was named Resid Efendi (a name he adopted in Constantinople), an explorer of the unknown world of the East. As the title of Mandler's book suggests, to the end of Vámbéry's life his spirit oscillated between the West and the East. His daring voyages to the mystical East were elevated in his writings to a legendary quest. Yet, notwithstanding his attraction to the East, which he himself presented before Western audiences with more than a touch of irony, Vámbéry invariably praised Western values and criticized Muslim views and perceptions.

Following his luminous travels and the fame he had achieved as a practicing Orientalist, Vámbéry wished to acquire a position as a teacher of Oriental languages at the University of Pest but was rejected by the university's academic committee. He then turned to the only possible instance of appeal available in such cases and asked for an audition with Kaiser Franz Joseph. The Emperor doubted whether there would be any students of Oriental languages at the Pest 
Szalai, Anna. "Mandler, David. 2014. Kelet és nyugat mezsgyéjén - Vámbéry Ármin és a Brit Birodalom ('On the Border between East and West - Arminius Vámbéry and the British Empire'). Budapest: Múlt és Jövő Kiadó. 223 pp." Hungarian Cultural Studies. e-Journal of the American Hungarian Educators Association, Volume 8 (2015): http://ahea.pitt.edu DOI: 10.5195/ahea.2015.205

University; nevertheless he accepted Vámbéry's request and used his power to nominate Vámbéry as professor in spite of the fact that he did not even possess a matriculation certificate. As for Vámbéry's mature family life, according to Mandler it is not clear whether it was the desire to belong to the Hungarian society or his sense of undecided identity that led Vámbéry to marry Kornélia Arányi, daughter of Lajos Arányi, a Protestant professor of pathology whose wife was Jewish.

Throughout his book, Mandler expresses appreciation of Vámbéry's work as a publicist, his complex political activity and action as an unflinching anti-Russian spy. Vámbéry's connections with Herzl, the Visionary of the (Jewish) State, also attest to Vámbéry's political influence; yet Mandler emphasizes that Vámbéry's mediation between Herzl and the Turkish Sultan did not stem from any Zionist convictions as Vámbéry's dream of a Jewish State was not one of mass migration but rather of creating a safe haven for persecuted Jews.

Despite its distinctly academic style, David Mandler's book on the life, journeys, writings and fascinating figure of Hungarian-Jewish Orientalist Ármin Vámbéry may capture the interest of audiences beyond students and researchers of Orientalism. Such readers would appreciate a mind-opening read about the mysterious figure of Vámbéry set in the context of the end of the Age of Empires, the rise of Zionism and -- focusing on Hungarian and Jewish history -- one of the most favorable periods for Hungarian Jews. 